\title{
KADAR VITAMIN C DAN ORGANOLEPTIK MANISAN BASAH LIDAH BUAYA (Aloe vera) PADA KONSENTRASI AIR KAPUR $\left(\mathrm{Ca}(\mathrm{OH})_{2}\right)$ YANG BERBEDA
}

\author{
Ike Apriani ${ }^{1}$, Meli Yani' \\ ${ }^{I}$ Dosen Prodi Biologi, FakultasSaintek, UIN Raden Fatah, Jl. Prof. K. H. ZainaL \\ Abidin Fikri No 1 A K M 3,5 Palembang 30126, Indonesia \\ ${ }^{2}$ Mahasiswa Prodi Pendidikan Biologi, FITK, UIN Raden Fatah, Jl. Prof. K. H. \\ ZainaL Abidin Fikri No 1 A K M 3,5 Palembang 30126, Indonesia \\ e-mail: ikeapriani_uin@radenfatah.ac.id
}

\begin{abstract}
Aloe vera is one species of Liliaceae that is able to grow in tropic area such as Indonesia. Aloe verahas potential as food, such as sweets. The slimy and soft texture of Aloe vera makes the problem of producing quality sweets products so it needs soaking with $\mathrm{Ca}(\mathrm{OH})_{2}$ solution.This study aims to determine the content of vitamin $\mathrm{C}$ and organoleptic in Aloe vera sweets with various concentrations of $\mathrm{Ca}(\mathrm{OH})_{2}$ solution. The research was conducted in March 2017 at Biology and ChemistryLaboratory,FTIKRaden Fatah State Islamic University. This research use experimental method, through experiment design used RAL one factor with concentration of $\mathrm{Ca}(\mathrm{OH})_{2}$ solution, consist of $\mathrm{K} 1=1 \%$, $\mathrm{K} 2=2 \%, \mathrm{~K} 3=3 \%$ and $\mathrm{K} 4=4 \%$ (5 repetitions). Research method using titration and hedonic method. The highest vitamin $\mathrm{C}$ levels were found in the treatment with the concentration of $\mathrm{Ca}(\mathrm{OH})_{2} \quad 1 \%$ solution ie 323.84 $\mathrm{mg} / 100 \mathrm{gr}$. Organoleptic test results obtained concentration of $\mathrm{Ca}(\mathrm{OH})_{2}$ $4 \%$ solution preferably by panelist.
\end{abstract}

Keyword: aloe vera, $\mathrm{Ca}(\mathrm{OH}) 2$, organoleptic,sweets

\section{PENDAHULUAN}

Lidah buaya (Aloe vera) diduga berasal dari Afrika dan telah dikenal sejak ribuan tahun silam. Tumbuhan ini termasuk family Liliaceae, yang memiliki daging daun tebal, panjang mengecil ke bagian ujungnya, berwarna hijau, berlendir, dan mudah tumbuh di daerah berhawa panas dan terbuka. Tumbuhan ini dapat tumbuh subur di Indonesia (Sudarto, 1997).

Tumbuhan lidah buaya dikenal sebagai tumbuhan penyubur rambut, penyembuh luka, perawat kulit, dan dapat menyembuhkan penyakit lainya (Sudarto, 1997). Manfaat tersebut dikarenakan tumbuhan ini memiliki berbagai efek fisiologis seperti hipokolesterolemia, antioksidatif, antikarsinogenik, dermatitis, antivirus, dan antiinflamasi, serta dapat memodulasi sistem imun (Elizabeth, 2001).

Banyaknya manfaat lidah buaya yang baik untuk kesehatan menjadikan tumbuhan ini berpotensi untuk dijadikan pangan fungsional. Menurut Furnawanthi (2002), pangan fungsional merupakan pangan yang tidak hanya berfungsi sebagai makanan atau minuman, tetapi memiliki efek lain yang menyehatkan. Biasanya,makanan dan minuman tersebut dibuat dari tumbuhan yang memiliki kandungan zat-zat atau senyawa yang secara klinis terbukti bermanfaat bagi kesehatan.

Salah satu fungsional adalah manisan. Menurut Alliceva (2010), manisan termasuk salah satu metode pengawetan produk buahbuahan yang paling tua. Pembuatan manisan menggunakan gula atau dengan cara 
merendam dan memanaskan buah dalam madu.

Rasa manis yang bercampur dengan rasa khas buah sangat cocok dinikmati dan disukai masyarakat. Pengelolahan aneka buah menjadi manisan buah basah atau manisan buah kering ini masih memiliki peluang usaha yang menjanjikan dan potensi penyerapan pasar yang cukup (Alliceva, 2010).

Kendala yang dihadapi dalam pembuatan manisan basah lidah buaya adalah tekstur lidah buaya yang lunak dan berlendir sehingga perlu dilakukan perendaman dalam larutan kapur $\mathrm{Ca}(\mathrm{OH})_{2}$. Menurut Utami (2007), perendaman kapur bertujuan untuk mempertahankan tekstur bahkan dapat memperbaiki tekstur lidah buaya yang lunak. Pemberian larutan kapur 6\% pada manisan tamarillo menghasilkan tingkat kerenyahan yang tepat. Hastuti $d k k$, (2013), menggunakan 2\%, 4\% dan 6\%larutan kapur $\mathrm{Ca}(\mathrm{OH})_{2}$ pada manisan rambutan.

Proses perendaman dengan larutan kapur dapat menurunkan kadar vitamin $\mathrm{C}$ dan berpengaruh terhadap organoleptik manisan lidah buaya. Berdasarkan hasil penelitian Hastuti, dkk., (2013), kadar vitamin $\mathrm{C}$ pada manisan rambutan kering yang menggunakan larutan kapur dengan konsentrasi $2 \%, 4 \%$ dan $6 \%$ adalah 1,789 $\mathrm{mg} / 5 \mathrm{gr} ; 1,789 \mathrm{mg} / 5 \mathrm{gr}$ dan $1,44 \mathrm{mg} / 5 \mathrm{gr}$. Penurunan kadar vitamin $\mathrm{C}$ disebabkan kondisi perendaman menjadi basa.

Agar mendapatkan manisan lidah buaya yang berkualitas dengan tekstur yang kenyaldanpenurunankadar vitamin $\mathrm{C}$ yang rendahmakaperludilakukankajianterhadapber bagaikonsentrasilarutanair kapur $\mathrm{Ca}(\mathrm{OH})_{2}$.

\section{METODE PENELITIAN}

\section{Tempat dan Waktu Penelitian}

Penelitian ini dilaksanakan di Laboratorium Biologi dan Kimia, Fakultas
Tarbiyah dan Keguruan UIN Raden Fatah Palembang pada bulan Maret tahun 2016.

Penelitian ini menggunakan metode eksperimen. Rancangan percobaan yang digunakan adalah Rancangan Acak Lengkap (RAL) dengan satu faktor yaitu konsentrasi larutan kapur, dimana perlakuan ada empat taraf yaitu simbol $\mathrm{K}_{1}=1 \%, \mathrm{~K}_{2}=2 \%, \mathrm{~K}_{3}=3 \%$ dan $\mathrm{K}_{4}=4 \%$ yang diulang sebanyak lima kali (5 kali ulangan), sehingga terdapat 25 unit percobaan. Data hasil penelitian yang diperoleh dianalisis menggunakan ANOVA.

Adapun alat yang digunakan dalam penelitian ini yaitu erlemeyer, gelas beaker, kertas saring, botol, pengaduk magnetic, tabung reaksi, pipet tetes, timbangan analitik, corong pendek, buret, blender, hot plate, mortal dan Bunsen.

Bahan yang dibutuhkan yaitu larutan amilum $1 \%$, akuades, Kapur sirih $\mathrm{Ca}(\mathrm{OH})_{2}$, larutan benadict, KI (Potassium Iodida), dan daun lidah buaya yang segar.

Uji Vitamin C menggunakan metode Iodimetri, dan uji organoleptik menggunakan motede hedonik.

\section{HASIL DAN PEMBAHASAN}

\section{Kadar Vitamin C pada manisan lidah Buaya}

Kadar vitamin $\mathrm{C}$ pada manisan lidah buaya dengan berbagai konsentrasi perendaman larutan kapur $\mathrm{Ca}(\mathrm{OH})_{2}$ dapat dilihat padaTabel 1.

Hasil penelitian ini menunjukan bahwa kadar vitamin $\mathrm{C}$ tertinggi pada perlakuan kosentrasi $1 \%$ sebesar 323,84 $\mathrm{mg} / 100 \mathrm{gr}$ dan kadar vitamin $\mathrm{C}$ terendah pada perlakuan kosentrasi $4 \%$ sebesar 98,56 mg/100gr. Semakin tinggi konsentrasi larutan kapur, maka kadar vitamin $\mathrm{C}$ akan semakin menurun. 
Tabel 1. Kadar Vitamin C padaManisanLidahBuayaBasah

\begin{tabular}{lc}
\hline Perlakuan & Kadar Vitamin C (mg/100gr) \\
\hline Kontrol & $246,52^{\mathrm{a}}$ \\
Kosentrasi 1\% & $323,84^{\mathrm{d}}$ \\
Kosentrasi 2\% & $267,6^{\mathrm{cd}}$ \\
Kosentrasi 3\% & $140,8^{\mathrm{ab}}$ \\
Kosentrasi 4\% & $98,56^{\mathrm{a}}$ \\
\hline
\end{tabular}

Buah mempunyai rasa asam, sedangkan larutan kapur bersifat basa kuat sehingga proses perendaman akan menetralkan asam. Menurut Carina dkk (2012), umumnya, zat-zat dengan sifat yang berlawanan, seperti asam dan basa cenderung bereaksi membentuk zat baru yaitu garam dan air. Bila larutan asam direaksikan dengan larutan basa, maka ion $\mathrm{OH}^{+}$dari asam akan beraksi dengan ion $\mathrm{OH}^{-}$dari basa membentuk molekul garam dan air. $\mathrm{C}_{6} \mathrm{H}_{8} \mathrm{O}_{6}$ (Asam Askorbat) akan melepaskan $2 \mathrm{H}^{+}$dan $\mathrm{Ca}(\mathrm{OH})_{2}$ (Kalsium Hidroksida) akan melepaskan $\mathrm{OH}^{-}$, sehingga $2 \mathrm{H}^{+}$akan bertemu dengan $\mathrm{OH}^{-}$dan membentuk $\mathrm{H}_{2} \mathrm{O}$ (Air). Kemudian $\mathrm{Ca}$ akan berikatan dengan $\mathrm{O}^{-}$.
Reaksi penetralan asam basa antara vitamin $\mathrm{C}$ dan kapur sebagai berikut:

$\mathrm{C}_{6} \mathrm{H}_{8} \mathrm{O}_{6}+\mathrm{Ca}(\mathrm{OH})_{2} \rightarrow \mathrm{Ca}\left(\mathrm{C}_{6} \mathrm{H}_{6} \mathrm{O}_{6}\right)+2 \mathrm{H}_{2} \mathrm{O}$.

Asam dehidroaskorbat $\mathrm{C}_{6} \mathrm{H}_{6} \mathrm{O}_{6}$ adalah bentuk dari asam askorbat (vitamin C) yang teroksidasi. Dalam pangan, Asam dehidroaskorbat dapat digunakan sebagai suplemen vitamin $\mathrm{C}$.

\section{Organoleptik Manisan Lidah Buaya}

Organoleptik manisan lidah buaya meliputi tekstur, warna, aroma dan rasa. Hasil organoleptik dengan metode hedonic dapat dilihat pada Tabel 2.

Tabel 2. Organoleptik Manisan Basah Lidah Buaya dengan Uji Hedonik

\begin{tabular}{lcccc}
\hline Perlakuan & Tekstur & Warna & Aroma & Rasa \\
\hline Kontrol & 1.5 & 3.7 & 1.3 & 1.2 \\
Kosentrasi 1\% & 1.9 & 3.4 & 1.7 & 1.5 \\
Kosentrasi 2\% & 2.4 & 3.1 & 2.1 & 2.1 \\
Kosentrasi 3\% & 2.7 & 2.7 & 2.1 & 2 \\
Kosentrasi 4\% & 3 & 2.5 & 2.4 & 2.4 \\
\hline
\end{tabular}

\section{Tekstur}

Skor 1.5 pada kontrol menyatakan bahwa tekstur tidak kenyal, sedangkan konsentrasi 1-3\% Ca(OH) $)_{2}$ tergolong sedikit kenyal. Konsentrasi $4 \quad \% \quad \mathrm{Ca}(\mathrm{OH})_{2}$ memilikitekstur yang kenyal dan lebih disukai panelis.

Air kapur $\mathrm{Ca}(\mathrm{OH})_{2}$ dapat mengubah tekstur lidah buaya yang tidak kenyal menjadi kenyal. Semakin tinggi nilai konsentrasi $\mathrm{Ca}(\mathrm{OH})_{2}$ maka tekstur manisan lidah buaya akan semakin kenyal. Hal ini sesuai dengan pernyataan Fatah dkk (2004), bahwa larutan kapur akan menguatkan tekstur bagian luar buah atau sayur yang akan diolah menjadi manisan.

\section{Warna}

Warna manisan lidah buaya tergolong agak putih dengan skor 3, pada kontrol, konsentrasi $1 \%$, dan konsentrasi $2 \%$. Sedangkan, warna kuning dengan skor 2 pada konsentrasi 3\% dan $4 \%$.

Warna merupakan salah satu indikator kualitas suatu produk pangan. Selain itu, warna sangat membantu dalam selera makan konsumen sehingga berperan penting untuk menentukan penerimaan konsumen. Menurut Pratama (2013), kualitas 
manisan lidah buaya dapat dilihat dari warnanya, semakin putih maka semakin baik produk manisan tersebut.

\section{Aroma}

Tabel 2, memperlihatkan bahwa perlakuan kontrol dan konsentrasi $1 \%$ dikatagorikan sangat berbau yang artinya, tidak disukai oleh panelis. Sedangkan, konsentrasi 2\%-4\% digolongkan berbau. Konsentrasi air kapur yang diberikan tidak memberikan efek perubahan terhadap aroma. Aroma makanan sangat penting karena akan mempengaruhi minat konsumen terhadap produk sebelum konsumen menikmati makanan tersebut.

\section{Rasa}

Rasa merupakan sensasi yang ditimbulkan oleh reseptor (taste buds) pada lidah dalam mulut. Rasa dapat meliputi, asam (sour), manis (sweet), asin (salt), dan pahit (bitter) (Pratama, 2013). Pada indikator Rasa, Perlakuan kontrol dan konsentrasi 1\% dikatagorikan tidak enak, sebagian panelis tidak suka. Sedangkan pada konsentrasi $2 \%$ $4 \%$ tergolong tidak begitu enak.

\section{SIMPULAN DAN SARAN} bahwa :

Dari penelitian dapat disimpulkan

1. Kadar vitamin $\mathrm{C}$ manisan lidah buaya pada perlakuan kontrol, konsentrasi $1 \%$, $2 \%$, 3\% dan 4\%, masing-masing 323.84 $\mathrm{mg} / 100 \mathrm{gr}, \quad 267.6 \mathrm{mg} / 100 \mathrm{gr}, \quad 140.8$ $\mathrm{mg} / 100 \mathrm{gr}, 98.56 \mathrm{mg} / 100 \mathrm{gr}$.

2. Tekstur yang disukai panelis adalah tekstur kenyal pada konsentrasi $4 \%$.

3. Warna agak putih pada perlakuan kontrol, konsentrasi 1\%, dan konsentrasi2\%. Sedangkan konsentrasi $3 \%$ dan $4 \%$ berwarna kuning.
4. Perlakuan kontrol dan konsentrasi $1 \%$ dikatagorikan sangat berbau dan konsentrasi 2\%-4\% digolongkan berbau.

5. Perlakuan kontrol dan konsentrasi $1 \%$ dikatagorikan tidak enak, Sedangkan konsentrasi 2\%-4\% tergolong tidak begitu enak.

\section{RUJUKAN}

Alliceva. 2010. Manisan Buah. http://alliceva.com. Diakses pada tanggal 2 februari 2017.

Carina C, Wignyanto W, Putri WI. 2012. Pengembangan belimbing wuluh (Averrhoa bilimbi) sebagai manisan kering dengan kajian kosentrasi perendaman air kapur $\mathrm{Ca}(\mathrm{OH})_{2}$ dan lama waktu pengeringan. Jurnal Industri. 1(3):195-203.

Elizabeth J. B. 2001. Aloe vera: Understanding it's Proposed Mecanism ofAction and Clinical Importance.(http: //umm.edu/altemed/articles/aloe000221.htm). University of Maryland. Diakses pada 11 Desember 2015.

Fatah, M. H. dan Bacthiar, Yusuf. 2004. Membuat Aneka Manisan Buah. Jakarta: AgroMedia Pustaka.

Furnawanthi, Irni. 2002. Khasiat dan manfaat Lidah Buaya si tanaman Ajaib. Jakarta: Penerbit Balai Pengkajian Bioteknologi (BPPT) dan Argo Media Pustaka.

Hastuti, S., Y. D. Kurnianti., dan M. Fakhry. 2013. Produksi manisan rambutan kering dengan variasi konsentrasi larutan kapur dan karakteristik pengeringan. Agrointek. 7 (1): 38-42.

Pratama, Fili. 2013. Evaluasi Sensoris. Palembang: Unsri Press.

Sudarto, Y. 1997. Lidah Buaya. Yogyakarta: Kanisius.

Utami, P. W. 2007. Pembuatan Manisan Tamarilo (Kajian konsentrasi Perendaman Air Kapur $\mathrm{Ca}(\mathrm{OH})_{2}$ dan Lama Pengeringan Terhadap Sifat Fisik, Kimia, dan Organoleptik). Skripsi. Jurusan THP, Fakultas Teknologi Pertanian Universitas Brawijaya. Malang. 